\title{
Factors affecting tax compliance of small and medium enterprises in Hung Yen province, Vietnam
}

\author{
Hien Thu Nguyen ${ }^{a^{*}}$
}

${ }^{a}$ Faculty of Accounting, Academy of Finance, No. 58, Le Van Hien St., Duc Thang Wrd., Bac Tu Liem Dist., Hanoi, Vietnam

\begin{tabular}{|c|c|}
\hline C H R O N I C L E & A B S T RA C T \\
\hline $\begin{array}{l}\text { Article history: } \\
\text { Received July } 9,2021 \\
\text { Received in revised format July } \\
202021 \\
\text { Accepted July } 302021 \\
\text { Available online } \\
\text { July } 302021 \\
\text { Keywords: } \\
\text { Tax compliance } \\
\text { Taxpayers }\end{array}$ & $\begin{array}{l}\text { Corporate tax compliance has been an interest of policymakers in many countries. Taxes } \\
\text { contribute the most to the government's revenues in Vietnam in general and in Hung Yen in } \\
\text { particular. Therefore, tax compliance of enterprises, including SMEs, attracts special concern of } \\
\text { the Government and many localities. The objective of this study is to evaluate factors affecting } \\
\text { tax compliance by examining } 310 \text { managers, tax accountants and accountants at SMEs in Hung } \\
\text { Yen province. The survey data is collected by the statistical software SPSS } 20 \text {. The experimental } \\
\text { research results confirm that factors (the possibility of tax inspection, tax rates, tax penalties, and } \\
\text { the complexity of tax policy, social norms and tax knowledge) have different influences on tax } \\
\text { compliance in SMEs in Hung Yen province, Vietnam. }\end{array}$ \\
\hline
\end{tabular}

SMES

Tax laws

\section{Introduction}

Taxes are considered the main source of the state's budget revenues. Taxation is an important tool for the state to regulate the macro economy, promote investments, control inflation, protect domestic production, conduct production and consumption, and redistribute wealth and income in the society. Therefore, tax compliance of taxpayers, especially enterprises, is a great concern of policymakers in many countries around the world. In Vietnam, the Government is always concerned about the tax administration, especially tax obligations of enterprises, because taxes are the most important revenues and contribute the most to the total state budget revenues. Hung Yen gained the total state budget revenue of 16,250 billion VND, reached 109.3\% of the plan, increased 1.27\% (Hung Yen Provincial People's Committee, 2020a) in 2020, and the main sources of revenues were from taxes and fees. However, there are some revenues and taxes accounting for a large proportion of the total state budget revenues have not been completed as planned (Hung Yen Provincial People's Committee, 2020b). Besides, there are many businesses in the province that have not fully fulfilled their tax obligations yet. This is reflected in the amount of tax arrears and tax fines in inspections as follows: as of December 2020, Hung Yen Department of Taxation inspected 625 cases, reached $73.6 \%$ of the plan, and collected 41.6 billion VND, fined 13.6 billion VND, reduced the loss of 132.8 billion, reduced the deduction of 15.2 billion (Tuan, 2020). On the other hand, Hung Yen is a province in the core economic zone in the North of Vietnam where many large industrial zones are located; the number of businesses has been increasing. According to Hung Yen Provincial People's Committee (2020b), the total number of registered enterprises is 12,110 , of which $72 \%$ are operating, the number of small and medium-sized enterprises (SMEs) accounts for about $94 \%$. As we can see from the data, the number of inspections that have been carried out still accounts for a small percentage compared to the number of enterprises in the province. Therefore, in order to stabilize and improve

* Corresponding author.

E-mail address: hiennt@hvtc.edu.vn (H. T. Nguyen) 
the state budget revenues in the coming time, state agencies, tax authorities of Hung Yen need to enhance inspections to reduce tax loss. Besides, there should be mechanisms and policies to improve tax compliance of taxpayers.

In fact, tax compliance is always a difficult problem for tax authorities because it is influenced by many different factors. Therefore, in order to identify factors affecting taxpayers' tax compliance, this study analyses the following ones (the possibility of tax inspection, tax rates, tax penalties, the complexity of tax policies, social norms and tax knowledge) which affect tax compliance of SMEs in Hung Yen province. The results will demonstrate the impact of each factor on tax compliance. Since then, this study gives some implications to increasing tax compliance of SMEs in Hung Yen province, Vietnam.

\section{Theoretical basis, hypotheses, and research models}

\subsection{The background related to the research}

This study uses the institutional theory that lacks principles, the theory of planned behaviours, and the theory of expected utility as a framework for factors affecting tax compliance.

The institutional theory lacks principles: This sociological theory supposes that individuals make decisions based on social values, it may be contradictions if separately considered, but balancing together, this will create behaviours considered "normal" by the society. This theory is aimed at social norms that affect tax compliance.

The theory of planned behaviours: According to Ajzen (1991) Human behaviours are the results of planning behaviours and their control or forecasted behaviours explained by behaviour trends. The awareness of behaviour control reflects the difficult level to perform behaviours and whether the implementation is controlled or not depends on the available resources and current opportunities. The application of this theory aims at attitudes, subjective standards and behaviour awareness affecting taxes.

The theory of expected utility: This theory assumes that individuals behave reasonably, which means economic humans are "rational" and unreasonable behaviours will be removed or will not play an important role (Von Neumann \& Morgenstern, 1944). Being applied to tax compliance behaviour, the expected utility theory states that taxpayers will determine the risks and uncertainty conditions by comparing their expected values. This theory aims to be tested or severely fined, which encourages taxpayers to comply with taxes better.

\subsection{Taxpayers' compliance}

Tax compliance is such a broad topic, so there are many different definitions depending on the nature and research participants. Tax compliance can be understood as the accurate declaration of income and expenses in accordance with tax laws (Alm et al., 1991) on time, without the enforcement of tax authorities (Jackson \& Milliron, 1986). According to Allingham \& Sandmo (1972), tax compliance is the decision to declare real income with tax authorities in terms of uncertainty. In other words, taxpayer can decide to declare the actual tax payable or less than the actual amount; their decision depends on the probability of being discovered and the rate of the penalty. Tax compliance reflects the taxpayer's willingness to pay taxes (Kirchler, 2007) under tax law to achieve a country's economic equilibrium (Andreoni et al., 1998). Based on the legal aspect, Tax compliance is the degree to which the subject complies with tax obligations as defined in tax law (James \& Alley, 1999), taxpayers submit tax returns at the appropriate time and fulfil their tax obligations in accordance with tax laws, and judicial decisions (Hamm, 1995) or submit and declare all information related to tax obligations, pay taxes fully and on time (Lewis et al., 2009). Taxpayers will make decisions about whether or not to comply with tax laws by considering incurred risks and benefits derived from undeclared earnings (Allingham \& Sandmo, 1972), therefore voluntary tax compliance is largely determined by the taxpayer's confidence in the tax authorities while compulsory tax compliance is largely based on the government power (Kirchler et al., 2008). Thus, taxpayer's tax compliance can be understood as taxpayers fully comply with tax obligations in accordance with the law, including tax registration, tax declaration, tax calculation, tax payment and other requirements on tax administration.

\subsection{Factors influencing tax compliance}

The possibility of tax inspections: Tax inspections are performed to assess the completeness and accuracy of information and documents in tax records or taxpayers' compliance with tax laws. Tax inspections have a positive effect on reducing tax evasion (Jackson \& Jaouen, 1989), which early prevents tax frauds and forces taxpayers to comply with tax laws. It seems that taxpayers are afraid of tax inspections more than tax fines (Muehlbacher \& Kirchler, 2010; Kastlunger et al., 2013), tax inspections increase the level of tax compliance (Kirchler, 2007). In self-declaration, self-calculation, and selfpayment tax systems, tax inspections play an essential role to enhance as well as positively impact taxpayers' voluntary compliance. Tax inspection probability is one of the most important factors influencing tax non-compliance (Manaye, 2018). 
Tax rate: In fact, the tax rate is an important factor determining tax compliance, although there has been much controversy about the correlation between tax rates and tax compliance (Kirchler, 2007). Some studies suggest that there is a correlation between tax rates and tax compliance. Collins \& Plumlee (1991) concludes that the higher tax rate is, the less taxpayers are likely to comply, or in other words, high tax rates lead to high tax non-compliance (Tilahun, 2019). When examining the effect of tax rates on tax evasion by considering the relationship between the tax table and the "evasion gap", Fisman \& Wei (2004) showed that the increase in tax rates is related to the increase in tax evasion. Higher tax rate products often have high tax loss. Mas'ud et al. (2014) found a negative relationship between tax rate and tax compliance. On the other hand, some studies have found that there is no relationship between tax rate and tax compliance. Baldry (1987) and Porcano (1988) concluded that there is no effect of the tax rate on taxpayer compliance or the effect is really minor (Inasius, 2015).

Tax penalties: many studies have examined the relationship between the level of tax compliance and the penalties for tax law violations. However, the results show that this relationship is not always the same. Many empirical studies show that tax compliance is influenced by detection and punishment factors (Swistak, 2016), because inspections and penalties force taxpayers to comply with tax laws (Lederman, 2003). Taxpayers are aware of tax evasion detected by tax authorities and tax penalties (Wahl et al., 2010), the fear of later criminal punishment has a strong influence on the decision to comply with tax laws (Hoekema, 1986). The higher tax penalties are, the less enterprises evade taxes (Marrelli, 1984; Marrelli \& Martina, 1988; Wang \& Conant, 1988; Gordon, 1990), the high or low penalty affects tax compliance (Friedland, 1982).

The complexity of tax policies: a complex tax system can negatively affect tax compliance because it creates barriers and higher compliance costs for taxpayers, reduces preferences and limits taxpayers' compliance ability. Saad (2014) examined the literature on tax complication and classified the flexibility of the tax system into "calculation, tax forms, compliance costs, principles and procedures". When considering Fischer's tax compliance model, Chau \& Leung (2009) asserted that the tax system must be simple, represented by simple and clear tax laws and procedures. A simple tax system and legal procedures will help taxpayers more easily understand their tax obligations and tax payable, which will increase tax compliance. Richardson (2006) conducted an investigation of tax evasion in 45 countries by looking at both economic and non-economic factors, which revealed that the tax complication was the most important and decisive factor affecting tax compliance.

Social norms: ethical and social norms are closely related to tax compliance (Battiston \& Gamba, 2013; Traxler, 2010; Fjeldstad \& Semboja, 2001; Battiston \& Gamba, 2016), and have influence on the intention of complying taxes. (Bobek et al., 2007). Social pressures cause a strong positive impact on taxpayers' voluntary tax compliance (Battiston \& Gamba, 2016). Taxpayers in a social community form compliance intentions because of social acceptance attitude (Benk et al., 2011). Conceptions as well as intangible social pressures will influence their tax compliance or non-compliance decisions (Alm \& McKee, 1998; Torgler, 2007; Jackson \& Milliron, 1986; Eriksen \& Fallan, 1996). If taxpayers find that noncompliance is common, they may also choose not to comply with the tax regulations (Kirchler et al., 2008). Consequently, social norms influence both voluntary and compulsory tax compliance (Liu, 2014).

The tax knowledge: the effects of tax knowledge on tax compliance have been described in various studies. Previous studies have demonstrated that tax knowledge is closely related to taxpayers' ability to understand tax laws, regulations and compliance (Singh \& Bhupalan, 2001). Eriksen \& Fallan (1996) supposed that taxpayers' education was an important factor affecting their general understanding of taxation, especially tax laws and regulations, a greater knowledge on taxes can improve tax attitudes, which in turn can increase compliance and reduce tax evasion. In contrast, the narrow knowledge on taxes has negative impacts (Lewis, 1982), and the knowledge on taxes is the strongest predictor affecting tax compliance (Inasius, 2015).

\subsection{Hypotheses and research models}

On the basis of the background theory and the results of previous studies on factors affecting tax compliance, this study builds six hypotheses as follows:
$\mathbf{H}_{1}$ : The higher the possibility of tax inspection is, the better the tax compliance of enterprises is.
$\mathbf{H}_{2}$ : When the tax rate decreases, tax compliance ability of enterprises increases.
$\mathbf{H}_{3}$ : The higher the level of sanctioning is, the better the tax compliance of enterprises is.
$\mathbf{H}_{4}$ : When the complexity of the tax policy decreases, tax compliance ability of enterprises increases.
H5: The higher the social norms are, the higher the tax compliance ability of enterprises is.
H6: The higher the tax knowledge is, the higher the tax compliance ability enterprises is.

Based on the above hypotheses, the proposed research model is described as shown in Fig. 1.

Regression model: based on the hypotheses and proposed research models, the expected regression equation reflects the relationship between "factors affecting tax compliance of SMEs" as follows:

$$
T C_{i}=\alpha+\beta_{1} T I_{i}+\beta_{2} T R_{i}+\beta_{3} T P_{i}+\beta_{4} C P_{i}+\beta_{5} S N_{i}+\beta_{6} T K_{i}+\varepsilon_{i}
$$


In which: $T C_{i}$ is tax compliance of SMEs according to $i$ sample; $\alpha$ : Constant term; $\beta_{i}$ : Coefficients of explanatory variables; $\varepsilon_{i}$ : Residual.

The variables TI, TR, TP, CP, SN and TK are the possibility of tax inspection, the tax rates, the tax penalties, the complexity of tax policies, social norms and the tax knowledge.

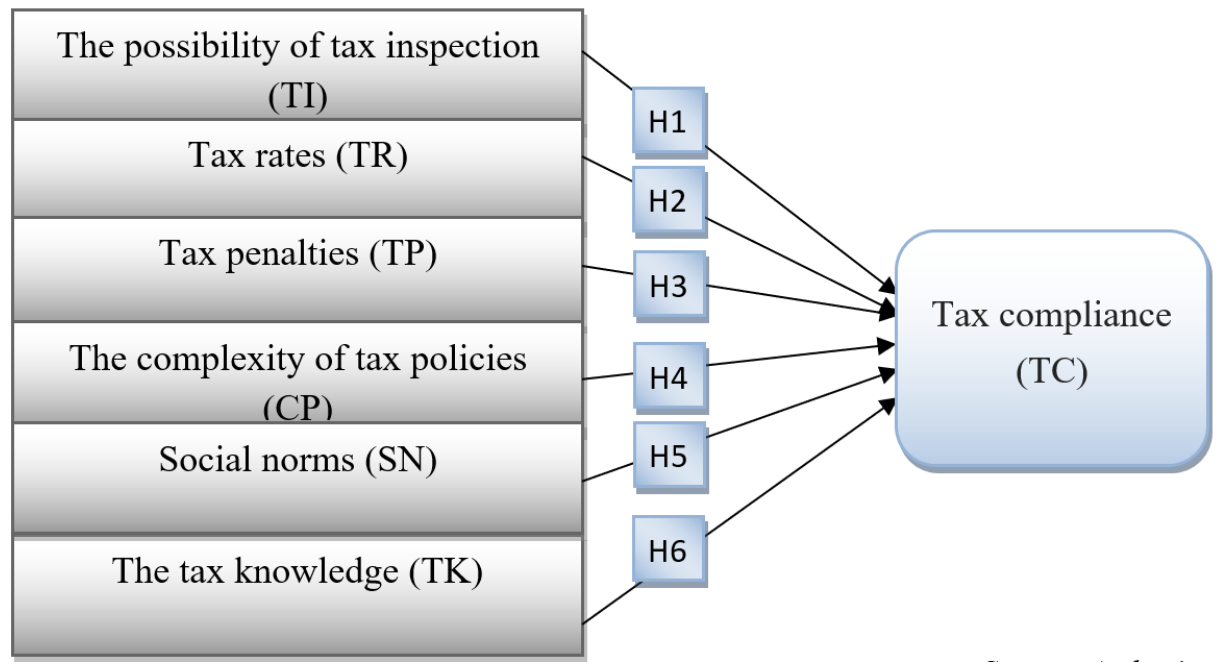

Source: Author's research

Fig. 1. Proposed research model

\section{Research method}

\subsection{Data collection methods}

The study data is collected through secondary data sources and primary data sources. The secondary data is collected from conferences, seminars, scientific topics, articles... related to the research. The primary data was collected from the survey using a detailed survey questionnaire with a 5-level Likert scale (Likert scale is used to evaluate the judgments about factors affecting the tax compliance, from 1: Strongly disagree to 5: Strongly agree) through face-to-face interviews or randomly email, post office to 350 managers (directors, deputy directors, chief accountants) and accountants (tax accountants and other accountants) in SMEs in Hung Yen province. The results obtained 310 valid survey questionnaires (reaching the rate of $88 \%$ ) and included in the study. The time for the survey is from November 2020 to February 2021. In this survey, details of firm size and respondents are shown in Fig. 2 and Fig. 3.

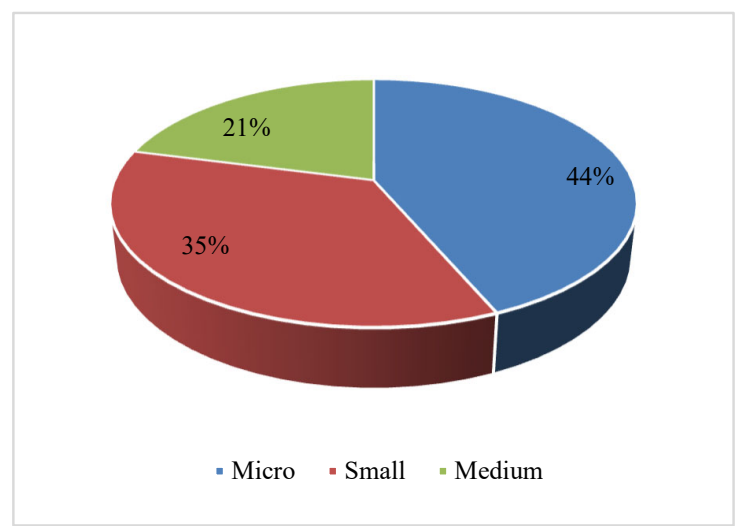

Fig. 2. The size of surveyed firms

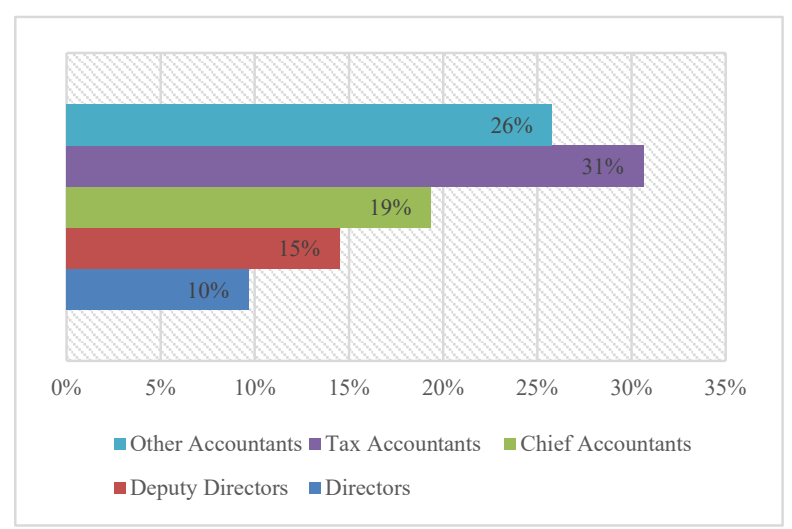

Fig. 3. Respondents

Determining the sample size: In exploratory factor analysis (EFA), the sample size must be 4 or 5 times than the number of variables (Hoang \& Chu, 2008); In practical research, sample sizes are usually 150 or larger (Gerbing \& Anderson, 1988). 


\subsection{Data analysis method}

The study uses statistical software SPSS 20 for descriptive statistical analysis through multi-variable linear regression model with criteria such as: Cronbach's Alpha test to assess the reliability of the scale, EFA analysis to reduce observed variables into more meaningful factors, testing the linear regression model to determine the correlation between factors and the tax compliance.

\subsection{The meaning of the variables in the study}

The research's variables are built and developed from the theoretical basis. They are also previous studies' results, which combine with the adjustment and new construction of a number of observed variables suitable to the reality and description in Table 1.

Table 1

The meaning of variables in the research

\begin{tabular}{ll}
\hline \multicolumn{1}{c}{ Group factor } & \multicolumn{1}{c}{ The meaning of variables } \\
\hline $\begin{array}{l}\text { The possibility of tax } \\
\text { inspection (TI) }\end{array}$ & $\begin{array}{l}\text { Three observed variables include: Enterprises will be inspected due to intentional tax frauds (TI1), When being } \\
\text { inspected, enterprises' frauds are likely to be discovered by tax authorities (TI2), enterprises' tax returns can be } \\
\text { tested (TI3). }\end{array}$ \\
Tax rates (TR) & $\begin{array}{l}\text { Four observed variables include: High tax rate applied to enterprises (TR1), The tax rate which is being applied is } \\
\text { not suitable for business's ability (TR2), Tax rates in the business sector of enterprises are higher than other areas } \\
\text { (TR3), Enterprises are not satisfied with tax rates and payable tax fees (TR4). }\end{array}$ \\
Tax penalties (TP) & $\begin{array}{l}\text { Four observed variables include: The penalties for non-compliance are relatively small (TP1), The penalties for non- } \\
\text { compliance are relatively high (TP2), The ability to be detected and punished for tax evasion is high (TP3), The } \\
\text { penalties for non-compliance are strict (TP4). }\end{array}$ \\
The complexity of tax & $\begin{array}{l}\text { Five observed variables include: The content of tax returns is confusing (CP1), It is not easy to calculate the tax } \\
\text { payable (CP2), Procedures for tax declaration or tax payment are very complicated (CP3), It takes a long time to pay } \\
\text { taxes (CP4), In general, the tax system in Vietnam is very complicated (CP5). }\end{array}$ \\
Thocial norms (SN) & $\begin{array}{l}\text { Three observed variables include: Tax evasion will be condemned by the society (SN1), Tax compliance is ethical } \\
\text { (SN2), Tax evasion is shameful and wrong (SN3). }\end{array}$ \\
The tax knowledge (TK) & $\begin{array}{l}\text { Five observed variables include: Understand tax principles (TK1), Understand regulations of filling and paying taxes } \\
\text { (TK2), Understand the rules governing tax rights and obligations (TK3), Understand the tax rates that apply to }\end{array}$ \\
businesses (TK4).
\end{tabular}

Source: The author' data synthesis

\section{The research results and discussion}

\subsection{Cronbach's Alpha scale reliability test}

Cronbach's Alpha coefficients are used to examine the degree of correlation between observed variables in the same factors included in the research model. Table 2's results show that all variables have Cronbach's alpha coefficients $>0.6$, so the scale can be used well and reliably (Hoang \& Chu, 2008). Thus, the results remain the observed variables belonging to the factor groups.

Table 2

Cronbach's Alpha tests

\begin{tabular}{llll}
\hline \multicolumn{2}{l}{ Component } & N of items & $\begin{array}{l}\text { Cronbach's } \\
\text { Alpha }\end{array}$ \\
\hline $\mathbf{1}$ & The possibility of tax inspection (TI) & 3 & 0.744 \\
$\mathbf{2}$ & Tax rates (TR) & 4 & 0.726 \\
$\mathbf{3}$ & Tax penalties (TP) & 4 & 0.725 \\
$\mathbf{4}$ & The complexity of tax policies (CP) & 5 & 0.804 \\
$\mathbf{5}$ & Social norms (SN) & 3 & 0.785 \\
$\mathbf{6}$ & The tax knowledge (TK) & 4 & 0.769 \\
$\mathbf{7}$ & Tax compliance (TC) & 4 & 0.798 \\
\hline
\end{tabular}

Source: Research results

\subsection{Exploratory Factor Analysis (EFA)}

EFA analysis was performed to group observed variables with linear relationships into more meaningful groups in order to reduce the regression model and eliminate variables with no practical significance. The analysis results of the scale of factors affecting the tax compliance show that the coefficient $\mathrm{KMO}=0.718$ (satisfying $0.5 \leq \mathrm{KMO} \leq 1$ ) should meet the requirements, and Bartlett's test has Sig. $=0.000<5 \%$ (Table 3). Therefore, these observed variables are mutually related and are suitable for EFA analysis. Total variance extracted is $61.217 \%>50 \%$, at Eigenvalues $=1.422>1$ (Table 4$)$, meets the requirements (Gerbing \& Anderson, 1988). The characteristic variables all have factor loading coefficients $>0.5$ (Table 5), so they are satisfactory (Hair et al., 1998). Thus, the results of EFA analysis are completely appropriate; the extracted factors are reliable and valuable. 
Table 3

KMO and Bartlett's Test

Kaiser-Meyer-Olkin Measure of Sampling Adequacy

Bartlett's Test of Sphericity

Source: Research results

Table 4

Total Variance Explained

\begin{tabular}{|c|c|c|c|c|c|c|c|c|c|}
\hline \multirow[t]{2}{*}{ Component } & \multicolumn{3}{|c|}{ Initial Eigenvalues } & \multicolumn{3}{|c|}{ Extraction Sums of Squared Loadings } & \multicolumn{3}{|c|}{ Rotation Sums of Squared Loadings } \\
\hline & Total & $\begin{array}{c}\% \text { of } \\
\text { Variance }\end{array}$ & Cumulative \% & Total & $\begin{array}{c}\% \text { of } \\
\text { Variance }\end{array}$ & Cumulative \% & Total & $\begin{array}{c}\% \text { of } \\
\text { Variance }\end{array}$ & Cumulative \% \\
\hline 1 & 3.969 & 17.255 & 17.255 & 3.969 & 17.255 & 17.255 & 2.882 & 12.531 & 12.531 \\
\hline 2 & 2.530 & 11.001 & 28.256 & 2.530 & 11.001 & 28.256 & 2.415 & 10.501 & 23.032 \\
\hline 3 & 2.283 & 9.924 & 38.181 & 2.283 & 9.924 & 38.181 & 2.296 & 9.981 & 33.013 \\
\hline 4 & 2.087 & 9.073 & 47.253 & 2.087 & 9.073 & 47.253 & 2.280 & 9.914 & 42.927 \\
\hline 5 & 1.790 & 7.782 & 55.035 & 1.790 & 7.782 & 55.035 & 2.129 & 9.257 & 52.184 \\
\hline 6 & 1.422 & 6.181 & 61.217 & 1.422 & 6.181 & 61.217 & 2.078 & 9.033 & 61.217 \\
\hline
\end{tabular}

Table 5

Rotated Component Matrix

\begin{tabular}{|c|c|c|c|c|c|c|}
\hline & \multicolumn{6}{|c|}{ Component } \\
\hline & 1 & 2 & 3 & 4 & 5 & 6 \\
\hline $\mathrm{CP} 1$ & 0.792 & & & & & \\
\hline $\mathrm{CP} 4$ & 0.757 & & & & & \\
\hline $\mathrm{CP} 2$ & 0.746 & & & & & \\
\hline CP3 & 0.726 & & & & & \\
\hline CP5 & 0.632 & & & & & \\
\hline TK2 & & 0.824 & & & & \\
\hline TK1 & & 0.758 & & & & \\
\hline TK3 & & 0.720 & & & & \\
\hline TK4 & & 0.720 & & & & \\
\hline TR1 & & & 0.817 & & & \\
\hline TR2 & & & 0.791 & & & \\
\hline TR3 & & & 0.735 & & & \\
\hline TR4 & & & 0.573 & & & \\
\hline TP1 & & & & 0.762 & & \\
\hline TP3 & & & & 0.723 & & \\
\hline TP2 & & & & 0.715 & & \\
\hline TP4 & & & & 0.714 & & \\
\hline SN3 & & & & & 0.906 & \\
\hline SN1 & & & & & 0.813 & \\
\hline SN2 & & & & & 0.768 & \\
\hline $\mathrm{TI} 3$ & & & & & & 0.828 \\
\hline TI2 & & & & & & 0.784 \\
\hline TI1 & & & & & & 0.766 \\
\hline
\end{tabular}

The analysis results of the scale of tax compliance show that the coefficient $\mathrm{KMO}=0.788$ (satisfying $0.5 \leq \mathrm{KMO} \leq 1$ ), the Bartlett's test has Sig. $<5 \%$ (Table 6) so the model is suitable for the analysis, the variables are correlated in the whole. Total variance extracted is $62.503 \%>50 \%$; Eigenvalues $=2.500>1$ (Table 7), the model is eligible for EFA analysis.

Table 6

KMO and Bartlett's Test

Kaiser-Meyer-Olkin Measure of Sampling Adequacy

Bartlett's Test of Sphericity

Table 7

Total Variance Explained

\begin{tabular}{cccccc}
\hline \multirow{2}{*}{ Component } & \multicolumn{3}{c}{ Initial Eigenvalues } & \multicolumn{2}{c}{ Extraction Sums of Squared Loadings } \\
\cline { 2 - 6 } & Total & \% of Variance & Cumulative \% & Total & \% of Variance \\
\hline 1 & 2.500 & 62.503 & 62.503 & 2.500 & 62.503 \\
2 & 0.611 & 15.272 & 77.775 & & \\
3 & 0.476 & 11.904 & 89.679 & & \\
4 & 0.413 & 10.321 & 100.000 & & \\
\hline
\end{tabular}


Table 8

\begin{tabular}{rrr}
\hline & \multicolumn{2}{c}{ Component } \\
& & 0.838 \\
TC4 & 0.813 \\
TC2 & 0.756 & 0.752 \\
TC1 & Source: Research results
\end{tabular}

Table 8 shows that the observed variables in tax compliance are satisfied (factor loading $>0.5$ ). Thus, after EFA analysis, there are still 04 (four) observed variables TC1, TC2, TC3, and TC4 of TC dependent variables.

\subsection{Multiple linear regression analysis}

To analyze the relationship between the dependent variables and the independent variables, test hypotheses, this study uses linear regression analysis. The test results show that adjusted $\mathrm{R}$ square $=60.4 \%$ (Table 9 ), which means that $60.4 \%$ of the variation of the dependent variable is explained by the independent variables. The ANOVA test has a value of Sig. $=0.000$ $<5 \%$ (Table 10) so the model is statistically significant and has at least one independent variable affecting dependent variables.

Table 9

Model Summary

\begin{tabular}{cccccc}
\hline Model & $\mathrm{R}$ & $\mathrm{R}$ Square & Adjusted R Square & Std. Error of the Estimate & Durbin-Watson \\
\hline 1 & 0.782 & 0.612 & 0.604 & 0.31135 & 1.743 \\
\hline & & & & Source: Research results
\end{tabular}

Table 10

\begin{tabular}{|c|c|c|c|c|c|c|}
\hline \multicolumn{2}{|r|}{ Model } & Sum of Squares & df & Mean Square & $\mathrm{F}$ & Sig. \\
\hline \multirow{3}{*}{1} & Regression & 46.280 & 6 & 7.713 & 79.568 & 0.000 \\
\hline & Residual & 29.373 & 303 & 0.097 & & \\
\hline & Total & 75.652 & 309 & & & \\
\hline
\end{tabular}

Source: Research results

Table 11 shows that the independent variables have the value Sig. $<5 \%$, so the regression model has statistical significance, consistent with the data. They can be used, which means independent variables TR, CP, TI, TP, TK and SN affect the dependent variable TC. The variance magnification coefficient is $<2.20$, so the multi-collinearity phenomenon is not violated (Nguyen, 2011).

Table 11

The coefficients of the regression analysis

\begin{tabular}{|c|c|c|c|c|c|c|c|c|}
\hline & \multirow[t]{2}{*}{ Model } & \multicolumn{2}{|c|}{$\begin{array}{l}\text { Unstandardized } \\
\text { Coefficients }\end{array}$} & \multirow{2}{*}{$\begin{array}{c}\begin{array}{c}\text { Standardized } \\
\text { Coefficients }\end{array} \\
\text { Beta }\end{array}$} & \multirow[t]{2}{*}{$\mathbf{t}$} & \multirow[t]{2}{*}{ Sig. } & \multicolumn{2}{|c|}{ Collinearity Statistics } \\
\hline & & B & Std. Error & & & & Tolerance & $\begin{array}{c}\text { Collinearity Statistics } \\
\text { (VIF) }\end{array}$ \\
\hline \multirow{7}{*}{1} & (Constant) & -1.115 & 0.248 & & -4.503 & 0.000 & & \\
\hline & $\mathrm{TR}$ & 0.163 & 0.037 & 0.163 & 4.386 & 0.000 & 0.927 & 1.079 \\
\hline & $\mathrm{CP}$ & 0.442 & 0.047 & 0.367 & 9.430 & 0.000 & 0.845 & 1.183 \\
\hline & TI & 0.342 & 0.036 & 0.359 & 9.515 & 0.000 & 0.901 & 1.110 \\
\hline & $\mathrm{TP}$ & 0.176 & 0.023 & 0.283 & 7.668 & 0.000 & 0.941 & 1.062 \\
\hline & TK & 0.149 & 0.033 & 0.169 & 4.504 & 0.000 & 0.908 & 1.101 \\
\hline & SN & 0.059 & 0.025 & 0.087 & 2.382 & 0.018 & 0.962 & 1.040 \\
\hline
\end{tabular}

Thus, the results of hypothesis testing by multiple linear regression models show that the normalized regression coefficients (Beta) of independent variables are statistically significant, namely TI $(\beta=0.359)$, TR $(\beta=0.163)$, TP $(\beta=0.283)$, CP $(\beta=$ $0.367)$, SN $(\beta=0.087)$ and TK $(\beta=0.169)$. The standardized regression equation of this study is formulated as follows:

$$
T C=0.359 \times T I+0.163 \times T R+0.283 \times T P+0.367 \times C P+0.087 \times S N+0.169 \times T K
$$

\section{The discussion on research results}

The results of multiple linear regression analysis (Table 11) show all six factors in the research model influence tax compliance. In which, the factor of complexity of tax policies (CP) is the main factor and has the strongest influence on tax compliance, with a beta coefficient of 0.367 . The possibility of tax inspections (TI) is the next major factor influencing tax compliance with the beta coefficient of 0.359 , followed by TP $(\beta=0.283)$, TK $(\beta=0.169)$, TR $(\beta=0.163)$ and SN $(\beta=$ 0.087). The results of this study are interpreted as follows: 
The possibility of tax inspection and tax compliance: the findings of the study show that the possibility of tax inspection is one of the most important factors affecting tax compliance of enterprises. This can be understood that the high possibility of tax inspection will increase tax compliance of businesses. Research results imply that, in the method of tax administration according to the mechanism of self-declaration, self-calculation and self-payment, enterprises base on the law provisions to determine their tax obligations, declare and pay taxes into the state budget, and take responsibility before the law for their truthful and accurate declaration. Therefore, it seems that businesses do not want to be inspected by tax authorities, because of the high possibility of being inspected and detected by tax authorities. The high possibility of being inspected and detected by tax authorities can increase corporate tax costs. The penalties for non-compliance are high, which poses higher risks to the business operations. On the other hand, businesses are aware that if tax evasion is detected by tax authorities, the penalties are really strict. This practice encourages businesses to comply with tax laws. This result is consistent with those of Kirchler (2007), Jackson \& Jaouen (1989) and Manaye (2018).

Tax rates and tax compliance: the tax rate is a factor that significantly affects corporate tax compliance. The research results show that, when the tax rate decreases, corporate tax compliance tax increases, and vice versa, the high tax rate causes high tax non-compliance. These findings explain that a high tax rate can discourage taxpayers, and the higher the tax rate is, the more likely people avoid declaring taxable income. This creates the hiding of revenues, income or vice versa, enterprises will record the higher costs or the lower import price in order to pay low taxes ... On the other hand, high tax rates will cause more tax evasion, because tax obligations may become a burden which is inconsistent with enterprises' ability, so tax evasion, tax fraud is the only way to ensure income for business activities. Thus, it can be affirmed that higher tax rates lead to less compliance of taxpayers or high tax non-compliance. This study result is consistent with the research of Kirchler (2007), Collins \& Plumlee (1991), Tilahun (2019) and Fisman \& Wei (2004).

Tax penalties and tax compliance: tax penalties are the next factor that has a positive impact on the tax compliance of enterprises. This result confirms that the higher the penalty is, the higher tax compliance is, because the penalty is a measure that forces taxpayers to comply with tax laws. Tax non-compliance behaviours will be strictly punished. Taxpayers who violate tax laws, in addition to being administratively sanctioned, are also sanctioned for tax evasion, even criminal penalties. A severe penalty for an offense will cause taxpayers to consider more carefully between the adverse consequences of being discovered and the benefits of tax evasion. Taxpayers who violate tax laws, in addition to being administratively sanctioned, may be subject to criminal prosecution. A severe penalty will cause taxpayers to consider more carefully between the adverse consequences of being discovered and the benefits of tax evasion. Taxpayers are aware that tax noncompliance can be detected by the tax authorities and severely punished, as well as fear of future criminal penalties. On the contrary, the low tax penalty will not ensure prevention, which is one of the reasons for the increase in tax evasion. The results of this study are similar to those of Swistak (2016), Hoekema (1986), Marrelli (1984), Marrelli \& Martina (1988), Wang \& Conant (1988) and Gordon (1990).

The complexity of tax policies and tax compliance: the complexity of the tax policy appears to be the most important factor influencing corporate tax compliance. This result shows that when the complexity of tax policy decreases (simple and clear tax laws and procedures), firms' tax compliance ability increases. These findings show that the system of tax regulations and policies in Vietnam in recent years has changed frequently. There are many new procedures, some of which are uncertain and complex, even the implementation of policies at tax agencies is not consistent, so taxpayers are more susceptible to violation because they cannot fully understand the changes in tax policies and procedures. On the other hand, the guidelines for the regulation implementation are not detailed, clear and public, so businesses have little information. Due to the complexity of the tax policy together with the tax administration method (self-declaration, self-calculation and self-payment), enterprises, especially SMEs will inevitably avoid incomplete declaration in tax records, and inaccurate tax obligations, which leads to an increase in tax non-compliance. Thus, it can be affirmed that businesses will increase their tax compliance if the tax laws and procedures are simple and clear. The findings of this study are consistent with those of Chau \& Leung (2009) and Richardson (2006).

Social norms and tax compliance: social norms are the next factor that positively influences corporate tax compliance, but the level of influence is negligible. This result confirms that, when social norms increase, corporate tax compliance increases, tax evasion is wrong, which will be condemned by the society. This may be due to the awareness of the people in general, taxpayers about law compliance; in which tax laws are not really good and still have many limitations. At the same time, Vietnam's cultural value system is currently significantly affected by globalization and economic development; especially some taxpayers have degraded ethical behaviours in value. Therefore, social norms have a relatively small impact on tax compliance. This result is consistent with those of Battiston \& Gamba (2013), Traxler (2010), Battiston \& Gamba (2016), Bobek et al. (2007) and Liu (2014).

Tax knowledge and tax compliance: tax knowledge is the next factor that has a significant positive impact on the tax compliance of businesses. The research results confirm that, when tax knowledge increases, taxpayers' ability to comply with tax increases as well. This can be understood that a taxpayer who is knowledgeable about tax laws, tax declaration and tax payment, tax obligations, and the tax rate applied to the business will likely increase tax compliance. In fact, in Vietnam, the current system of tax regulations and policies is complicated because there are so many laws, circulars, legal documents 
and tax policies constantly changing, so taxpayers face many difficulties in researching, tracking and updating changes, which leads to the lack of tax knowledge. In many cases, taxpayers commit unintentional serious mistakes due to the lack of tax knowledge. Therefore, in order to limit violations and increase tax compliance, it is necessary to improve taxpayers' tax knowledge by simplifying tax laws and strengthening the training and popularization of tax policies, which aims to improve taxpayers' attitude. This result is consistent with those of Singh \& Bhupalan (2001), Eriksen \& Fallan (1996) and Lewis (1982).

\section{Conclusion}

This study has examined factors that are likely to affect tax compliance of SMEs in Hung Yen province, Vietnam. Specifically, the study has conducted an empirical analysis of six factors affecting tax compliance (including: possibility of tax inspection, tax rates, penalties, complexity of tax policies, and tax knowledge) using SPSS 20 statistical software. The research results confirm that the complexity of tax policy is the most important and decisive factor affecting tax compliance of SMEs. A complicated, unsynchronized, and regularly supplemented tax system will make it difficult for taxpayers and tax authorities to implement, leading to an increase in tax non-compliance. Therefore, tax laws and procedures need to be simple and clear so that taxpayers can understand their tax obligations and calculate tax payable, which creates confidence in tax policy and increases tax compliance. Moreover, the possibilities of being taxed and punished are the next two factors positively on tax compliance. Taxpayers are often reluctant to receive tax inspection because the high possibility of inspection means their frauds could be detected by tax authorities and severely punished. At the same time, they are aware of the adverse consequences of tax evasion because in addition to administrative sanctions, tax evasion may also be subject to criminal prosecution. Therefore, tax authorities need to strengthen inspection and increase penalties when tax evasion is detected, which will contribute to raising awareness of tax compliance. Besides, the research results continue to confirm that tax knowledge and social norms are also two factors affecting tax compliance of taxpayers. However, social norms have a negligible influence on tax compliance, which affects at least one of the six factors included in the research model. Vietnam's cultural value is affected by globalization and the economy's rapid development, some taxpayers' ethical behaviours have degraded, which leads to the poor awareness of tax compliance. Besides, taxpayers lack knowledge about taxation because the tax system is complicated and being constantly changed. Therefore, it is necessary to improve taxpayers' compliance attitude through improving tax knowledge by simplifying tax laws, popularizing tax policies to create confidence in tax policies, at the same time help taxpayers understand their rights, obligations and responsibilities. The study results also confirm that the tax rate has an effect on the tax compliance of SMEs. The high tax rate will make taxpayers tend to hide their revenues, income or taxable price...when declaring in order to reduce the tax payable. On the other hand, high tax rates will become a tax burden and may discourage business expansion and investments, even cause tax evasion and tax arrears. Therefore, in order to minimize tax non-compliance, policy makers consider amending, supplementing or promulgating tax regulations and tax rates which must be suitable for practical conditions so as to avoid the "cascading tax" situation.

This research has achieved some significant results and contributed to the references for further studies on tax compliance through clarifying factors affecting tax compliance of SMEs in Hung Yen province, Vietnam. However, some certain limitations have been found in this study. In the first place, there may be other practical factors, such as tax ethics, the quality of tax services, the awareness of tax fairness...which may be important in determining tax compliance. However, these factors have not been fully considered in this study yet. Secondly, the sample used in the study may be small because it only includes SMEs in Hung Yen province. Therefore, it is not representative of all enterprises in the province and the whole country as well. The upcoming research should be expanded into further aspects such as the number of factors and sample sizes. Moreover, instead of surveying SMEs in Hung Yen, the next research should be carried out in other provinces in Vietnam, so they can provide diversified findings.

\section{References}

Ajzen, I. (1991). The theory of planned behavior. Organizational Behavior and Human Decision Processes, 50(2), 179211.

Allingham, M. G., \& Sandmo, A. (1972). Income tax evasion: a theoretical analysis. Journal of Public Economics, 1(3-4), $323-338$.

Alm, J., \& McKee, M. (1998). Extending the lessons of laboratory experiments on tax compliance to managerial and decision economics. Managerial and Decision Economics, 19(4-5), 259-275.

Alm, J., Bahl, R., \& Murray, M. N. (1991). Tax base erosion in developing countries. Economic Development and Cultural Change, 39(4), 849-872.

Andreoni, J., Erard, B., \& Feinstein, J. S. (1998). Tax compliance. Journal of Economic Literature, 36(2), 818-860.

Baldry, J. C. (1987). Income tax evasion and the tax schedule: Some experimental results. Public Finance, 43(3), 357-383.

Battiston, P., \& Gamba, S. (2013). Is Tax Compliance a Social Norm? A Field Experiment. SSRN Electronic Journal. doi: $10.2139 /$ ssrn. 2294384

Battiston, P., \& Gamba, S. (2016). The impact of social pressure on tax compliance: A field experiment. International Review of Law and Economics, 46, 78-85.

Benk, S., Cakmak, A. F., \& Budak, T. (2011). An investigation of tax compliance intention: A Theory of planned behavior 
approach. European Journal of Economics, Finance and Administrative Sciences, 28, 180-188.

Bobek, D. D., Hatfield, R. C., \& Wentzel, K. (2007). An Investigation of Why Taxpayers Prefer Refunds: A Theory of Planned Behavior Approach. The Journal of the American Taxation Association, 29(1), 93-111.

Chau, G., \& Leung, P. (2009). A Critical Review of Fischer Tax Compliance Model: A Research Synthesis. Journal of Accounting and Taxation, 1(2), 034-040.

Collins, J. H., \& Plumlee, R. D. (1991). The Taxpayer's Labor and Reporting Decision: The Effect of Audit Schemes. The Accounting Review, 66(3), 559-576.

Eriksen, K., \& Fallan, L. (1996). Tax knowledge and attitudes towards taxation; A report on a quasi-experiment. Journal of Economic Psychology, 17(3), 387-402.

Fisman, R., \& Wei, S. (2004). Tax Rates and Tax Evasion: Evidence from "Missing Imports" in China. Journal of Political Economy, 112(2), 471-496.

Fjeldstad, O., \& Semboja, J. (2001). Why People Pay Taxes: The Case of the Development Levy in Tanzania. World Development, 29(12), 2059-2074.

Friedland, N. (1982). A Note on Tax Evasion as a Function of the Quality of Information about the Magnitude and Credibility of Threatened Fines: Some Preliminary Research. Journal of Applied Social Psychology, 12(1), 54-59.

Gerbing, D. W., \& Anderson, J. C. (1988). Structural Equation Modeling in Practice: A Review and Recommended TwoStep Approach. Psychological Bulletin, 103(3), 411-423.

Gordon, J. P. F. (1990). Evanding taxes by selling for cash. Oxford Economic Papers, 42(1), 244-255.

Hair, J. F., Anderson, R. E., Tatham, R. L., \& Black, W. C. (1998). Multivariate data analysis (5th ed.). Englewood Cliffs, NJ: Prentice-Hall International, Inc.

Hamm, J. L. (1995). Income level and tax rate as determinants of taxpayer compliance: an experimental examination. Dissertation on Texas Tech University.

Hoang, T., \& Chu, N. M. N. (2008). Analyzing researched data with SPSS (2nd ed.). Ho Chi Minh City, Vietnam: Hong Duc Publishing House.

Hoekema, D. A. (1986). Rights and wrongs: Coercion, punishment, and the state. Susquehanna University Press.

Hung Yen Provincial People's Committee. (2020a). Socio-economic situation in December and the whole year 2020. Available at https://hungyen.gov.vn/portal/Pages/2020-12-31/Bao-cao-tinh-hinh-kinh-te--xa-hoi-thang-12-va-can8boqom.aspx

Hung Yen Provincial People's Committee. (2020b). Implementation of the socio-economic development plan 2020 and targets, tasks and solutions for 2021. Available at https://hungyen.gov.vn/portal/Pages/2020-12-10/Bao-cao-tinh-hinhthuc-hien-ke-hoach-phat-trien-kixdwxa6.aspx

Inasius, F. (2015). Tax compliance of small and medium enterprises: Evidence from Indonesia. Accounting \& Taxation, $7(1), 67-73$.

Jackson, B. R., \& Milliron, V. C. (1986). Tax compliance research: Findings, problems, and prospects. Journal of Accounting Literature, 5(1), 125-165.

Jackson, B., \& Jaouen, P. (1989). Influencing taxpayer compliance through sanction threat or appeals to conscience. Advances in Taxation, 2, 131-147.

James, S., \& Alley, C. (1999). Tax Compliance, Self-assessment, and Tax Administration in New Zealand: Is the Carrot or the Stick more Appropriate to Encourage Compliance?. New Zealand Journal of Taxation Law and Policy, 5(1), 3-14 .

Kastlunger, B., Lozza, E., Kirchler, E., \& Schabmann, A. (2013). Powerful authorities and trusting citizens: The Slippery Slope Framework and tax compliance in Italy. Journal of Economic Psychology, 34, 36-45.

Kirchler, E. (2007). The economic psychology of tax behaviour. Cambridge, England: Cambridge University Press.

Kirchler, E., Hoelzl, E., \& Wahl, I. (2008). Enforced versus voluntary tax compliance: The "slippery slope" framework. Journal of Economic Psychology, 29(2), 210-225.

Lederman, L. (2003). Interplay Between Norms and Enforcement in Tax Compliance. Journal Ohio Statet Law Journal, 64(6), 1453-1514.

Lewis, A. (1982). The psychology of taxation. Oxford, England: Martin Robertson.

Lewis, A., Carrera, S., Cullis, J., \& Jones, P. (2009). Individual, cognitive and cultural differences in tax compliance: UK and Italy compared. Journal of Economic Psychology, 30(3), 431-445.

Liu, X. (2014). Use Tax Compliance: The Role of Norms, Audit Probability, and Sanction Severity. Academy of Accounting and Financial Studies Journal, 18(1), 65-80.

Manaye, M. K. (2018). Determinants of Taxpayers' Voluntary Compliance with Taxation: The Case of Wolaita Sodo and Tercha Town in Dawuro Zone. Global Journal of Management and Business Research: D Accounting and Auditing, $18(3), 25-41$.

Marrelli, M. (1984). On indirect tax evasion. Journal of Public Economics, 25(1-2), 181-196.

Marrelli, M., \& Martina, R. (1988). Tax evasion and strategic behaviour of the firms. Journal of Public Economics, 37(1), 55-69.

Mas'ud, A., Aliyu, A. A., \& Gambo, E. J. (2014). Tax rate and tax compliance in Africa. European Journal of Accounting Auditing and Finance Research, 2(3), 22-30.

Muehlbacher, S., \& Kirchler, E. (2010). Tax Compliance by Trust and Power of Authorities. International Economic Journal, 24(4), 607-610.

Nguyen, D. T. (2011). Methods of scientific research in business. Labor and Social Publishing House, Hanoi. 
Porcano, T. M. (1988). Correlates of tax evasion. Journal of Economic Psychology, 9(1), 47-67.

Richardson, G. (2006). Determinants of tax evasion: A cross-country investigation. Journal of International Accounting, Auditing and Taxation, 15(2), 150-169.

Saad, N. (2014). Tax Knowledge, Tax Complexity and Tax Compliance: Taxpayers' View. Procedia - Social and Behavioral Sciences, 109, 1069-1075.

Singh, V., \& Bhupalan, R. (2001). The Malaysian Self Assessment System of Taxation: Issues and Challenges. Tax National, 3, 12-17.

Swistak, A. (2016). Tax penalties in SME tax compliance. Financial Theory and Practice, 40(1), 129-147.

Tilahun, M. (2019). Determinants of Tax Compliance: a Systematic Review. Economics, 8(1), 1-7.

Torgler, B. (2007). Tax compliance and taxmorale: A theoretical and empirical analysis. Cheltenham, England: Edward Elgar.

Traxler, C. (2010). Social norms and conditional cooperative taxpayers. European Journal of Political Economy, 26(1), 89103.

Tuan, V. (2020). Hung Yen: Increasing budget revenue from tax inspection and examination. Available at http://thoibaotaichinhvietnam.vn/pages/thue-voi-cuoc-song/2020-12-29/hung-yen-tang-thu-ngan-sach-tu-thanh-trakiem-tra-thue-97540.aspx

Von Neumann, J., \& Morgenstern, O. (1944). Theory of games and economic behavior. Princeton University Press.

Wahl, I., Kastlunger, B., \& Kirchler, E. (2010). Trust in Authorities and Power to Enforce Tax Compliance: An Empirical Analysis of the "Slippery Slope Framework". Law \& Policy, 32(4), 383-406.

Wang, L. F. S., \& Conant, J. L. (1988). Corporate Tax Evasion and Output Decisions of the Uncertain Monopolist. National Tax Journal, 41(4), 579-581. 
(C) 2022 by the authors; licensee Growing Science, Canada. This is an open access article distributed under the terms and conditions of the Creative Commons Attribution (CC-BY) license (http://creativecommons.org/licenses/by/4.0/). 